\title{
LEGALIDADE TRIBUTÁRIA OU LEI DA SELVA: SONHO OU PESADELO
}

\section{José Roberto Vieira}

Mestre e Doutor em Direito do Estado - Direito Tributário pela PUC/ SP, Professor de Direito Tributário da UFPR e da Faculdade de Direito das Faculdades Integradas Curitiba, Estudos Pós-Graduados no Instituto de Estudios Fiscales na Espanha, Auditor da Receita Federal, Membro Julgador do Conselho de Contribuintes do Ministério da Fazenda.

SUMÁRIO: 1 Lei do estado ou lei da selva; 2 República e democracia; 3 Legalidade; 3.1 Legalidade genérica; 3.2 Legalidade tributária; 4 Sonho ou pesadelo.

\section{LEI DO ESTADO OU LEI DA SELVA}

Numa obra tão concisa e didática quanto inspirada, RÉGIS DEBRAY, o professor e filósofo da França, ao explicar à sua filha adolescente o que é uma República, mais especificamente, ao falar daquilo que ele chama "El coraje de la ley", diante da pergunta de sua jovem interlocutora - "Cuál?" assim lhe responde: "Hay sólo dos. La ley del Estado y la ley de la jungla. La ley para todos o la ley de la calle, es decir, cuando el grande se come al pequeño". (grifamos) $)^{1}$

Não se trata aqui de estabelecer um radicalismo absoluto: ou a regra estatal ou fatalmente a regra da jângal. A humanidade e a vida, inclusive a jurídica e a política, não são maniqueístas assim. Há numerosos, talvez inúmeros, graus de legalidade e de legitimidade. Há fartas, talvez intermináveis, gradações republicanas e democráticas. Trata-se, isso sim, de uma opção de tendência no evolver do estado, de uma escolha de direção no quotidiano da vida pública: ou nos inclinamos, a cada passo, no sentido da legalidade, inclusive a tributária, no sentido republicano e democrático, ou - e aqui se trata de alternativa efetivamente extremada e drástica - caminhamos, a cada passo, em direção à mata original, melhor dizendo, "de volta" à floresta primitiva.

1 La república explicada a mi hija. Trad. Sandra Garzonio, Buenos Aires, Fondo de Cultura Económica, 1999 , p. 45. No que tange ao título, preferimos a versão argentina à espanhola - El civismo explicado a mi hija, trad. Manuel Serrat Crespo, Barcelona, Muchnik, 2000 - por uma questão de precisão, que principia pelo título original - La république expliquée à ma fille, Paris, Seuil, 1998 - e encontra definitiva razão de ser no seu conteúdo, que, embora igualmente "cívico", é caracteristicamente "republicano". 


\section{REPÚBLICA E DEMOCRACIA}

Eis dois portos inevitáveis antes de atracarmos na terra da legalidade, sob pena de ignorarmos o amplo contexto em que ela se localiza. ${ }^{2}$

Uma palavra inicial quanto à importância desses temas, essenciais à Política e ao Direito Público, irônica e saborosamente ilustrada por FERNANDO SAVATER, o filósofo da Universidade Complutense de Madri, quando nos lembra que os antigos gregos chamavam aos desinteressados na Política de idiotés, significando pessoa isolada, que nada tinha a oferecer aos demais. E completa: "Desse idiotés grego deriva nosso idiota atual, que não preciso explicar o que significa". Parafraseando SAVATER, e de forma até “...um pouco agressiva e irreverente...", como ele a define, mas perfeitamente lógica e etimológica, diríamos que "só não se interessam por esses temas aqueles que se aproximam da idiotice!"3

Embora falando da república, DEBRAY enuncia idéia plenamente aplicável também à democracia: “...nunca se realiza. Seguramente es irrealizable. Todas las repúblicas que existen son esbozos relativos, inferiores a sus principios" (grifamos). ${ }^{4}$ Trata-se de certeza antiga. Já em meados do século XVIII, afirmava JEAN-JACQUES ROUSSEAU, aqui se referindo à democracia, mas novamente numa idéia comum a ambas: “...no rigor da acepção, jamais existiu, jamais existirá uma democracia verdadeira”, cuja força o filósofo bem exprime pela hipérbole de reservá-la a uma eventual sociedade divina: "Se existisse um povo de deuses, governar-se-ia democraticamente". 5 Por isso, JUAN RAMÓN CAPELLA, o catedrático de Barcelona, entre outros, observa que “...os processos de democratização são ainda embrionários nas sociedades contemporâneas...”. ${ }^{6}$ Aqui, aliás, presente já a noção de democracia (república também,

2 Reproduzimos aqui parte da meditação que desenvolvemos acerca dessas noções, em outro artigo igualmente destinado à Revista da Faculdade de Direito da UFPR - República e democracia: óbvios ululantes e não ululantes - porque as julgamos adequadas à preparação zelosa do terreno da legalidade, a ser adiante cultivado.

3 Política para meu filho. Trad. Eduardo Brandão, São Paulo: Martins Fontes, 1996, p. 16-17. Trata-se de obra curiosamente semelhante à de DEBRAY, em sua concepção, na qual o autor escreve a seu filho, Amador, também adolescente, explicando-lhe o que é política (no original espanhol: Política para amador, Barcelona: Ariel, 1992); e que vem, aliás, na esteira de outro trabalho de SAVATER, este ainda mais admirável, fazendo o mesmo com a noção de ética: Ética para meu filho, trad. Monica Stahel, São Paulo: Martins Fontes, 1993 (no original espanhol: Ética para amador, Barcelona, Ariel, 1991), do qual há reedição recente, acrescida de um apêndice (Ética para amador, 3. ed., Buenos Aires: Ariel, 2001).

4 La república..., op. cit., p. 81.

5 Do contrato social ou princípios do direito político. In: Rousseau, trad. Lourdes Santos Machado (Os Pensadores, XXIV), São Paulo: Abril Cultural, 1973, p. 90 e 92.

6 Os cidadãos servos. Trad. Lédio Rosa de Andrade e Têmis Correia Soares, Porto Alegre: Fabris, 1998, p. 69. 
diríamos) como processo, sublinhada por JOSÉ AFONSO DA SILVA, que revela certa impaciência com a "...tese pessimista, se não de fundo elitista, segundo a qual a democracia nunca fora realizada em sua pureza em lugar algum", assentando: "Os que assim pensam não concebem que a democracia seja um processo... Como tal a democracia nunca se realizará inteiramente...".?

Com efeito, república e democracia são noções que indubitavelmente funcionam como ideais-limites, na expressão confiável de NORBERTO BOBBIO. ${ }^{8}$ E ideais-limites nitidamente perseguidos pelo movimento jurídico e político dos homens e seus estados, mas num compasso assim descrito, em 1886, por FRIEDRICH NIETZSCHE, cujo verbo filosoficamente profundo e estilisticamente belo era certamente livre, solto e ousado como o de poucos: “...o seu ritmo é demasiado vagaroso e sonolento para os mais impacientes... atestam os uivos cada vez mais raivosos, o ranger de dentes cada vez mais ostensivo dos cães anarquistas...". 9 Aliás, já em 1878, referindo-se a um sistema político em que o governo fosse um órgão do povo, NIETZSCHE afirmava tratar-se, num vaticínio que o tempo demonstraria demasiado otimista, de um novíssimo conceito que se apoderaria de todas as cabeças, acrescentando, porém: "...para o que, no entanto, talvez necessite de mais um século". ${ }^{10}$

Em termos republicanos e democráticos encontramo-nos também nós, brasileiros, em tenra idade, pois, na palavra inspirada de CÁRMEN LÚCIA ANTUNES ROCHA, nossa república (e democracia, agregaríamos) foi “...proclamada, conquanto não efetiva, nem definitivamente... realizada...”; pior, trata-se de "...uma República ainda muito mal praticada..."; e pior ainda, confessemos possuir uma "...parca República vivida pelo Brasil”. ${ }^{11}$

Perante nossa infância republicano-democrática, nada mais adequado do que olhar para a primeira dessas noções com intuitos minimamente conceptuais. República, do latim res publica, significa "coisa pública", "coisa comum”, como esclarece o etimologista (ANTÔNIO GERALDO DA CUNHA) ${ }^{12}$ e confirma o filósofo (RÉGIS DEBRAY), adicionando este: "Es el término ge-

7 Poder constituinte e poder popular (Estudos sobre a constituição). São Paulo: Malheiros, 2000, p. 45.

8 Igualdade e liberdade. Trad. Carlos Nelson Coutinho, 3. ed., Rio de Janeiro: Ediouro, 1997, p. 8.

9 Além do bem e do mal: Prelúdio a uma filosofia do futuro. Trad. Paulo César de Souza, 2. ed., São Paulo: Companhia das Letras, 1992, p. 102.

10 Humano, demasiado humano: Um livro para espíritos livres. Trad. Paulo César de Souza, São Paulo: Companhia das Letras, 2000, p. 243.

11 República e federação no Brasil: Traços constitucionais da organização política brasileira. Belo Horizonte: Del Rey, 1997, p. 17, 73 e 85.

12 CUNHA, Antônio Geraldo da. Dicionário etimológico nova fronteira da língua portuguesa. 2. ed. Rio de Janeiro: Nova Fronteira, 1996, p. 677. 
nérico que empleaban los antiguos filósofos... para designar a cualquier Estado regido por leyes". ${ }^{13}$ Tal confirmação já é secular, como se vê em ROUSSEAU: "Chamo pois de república todo o Estado regido por leis..."; que aditava elucidativamente "...pois só nesse caso governa o interesse público e a coisa pública..." (grifamos). ${ }^{14}$ Tamanha a importância da idéia que não admira que EMMANUEL KANT, o velho filósofo de Königsberg, a tenha anunciado como primeiro artigo de um eventual acordo pela paz perpétua: “...a constituição de cada estado deve ser republicana"; ${ }^{15}$ e não admira que FERNANDO SAVATER, o filósofo contemporâneo de Madri, tenha registrado que “...o mínimo que um país no século XX merece é um regime republicano". ${ }^{16}$

Voltemo-nos para a realidade nacional. Nosso Estatuto Magno não só afirma, logo no primeiro momento do texto, o Princípio da República (art. $1^{\mathrm{o}}$ ), mas também erige seu núcleo essencial em cláusula imutável (art. 60, § 4º, II), apenando sua inobservância com a severidade da intervenção federal nos estados (art. 34, VII, a). ${ }^{17}$

É este "...o princípio mais importante e decisivo do nosso direito público”, “...a síntese de todas as nossas instituições”, na apreciação de GERALDO ATALIBA, insuperável na acuidade com que mergulhou em todos os meandros e escaninhos da complexa noção. ${ }^{18}$

13 La república, op. cit., p. 19.

14 Do Contrato Social..., op. cit., p. 61.

15 Apud NORBERTO BOBBIO. O futuro da democracia: uma defesa das regras do jogo. Trad. Marco Aurélio Nogueira, 3. ed. Rio de Janeiro: Paz e Terra, 1986, p. 38.

16 Política..., op. cit., p. 199.

17 Conquanto a doutrina constitucional brasileira, após o advento do texto de 1988, incline-se no sentido de que a República não mais constitui cláusula intocável, é evidente que, vencida, em 21 de abril de 1993, a possibilidade de revisão constitucional a respeito (art. $2^{\circ}$ do Ato das Disposições Constitucionais Transitórias), a sua idéia nuclear de representação (voto direto, secreto e universal - art. $60, \S 4^{\circ}$, II) segue presente, assim como a de temporariedade (voto periódico - art. $60, \S 4^{\circ}$, II), e até mesmo a de igualdade, para aqueles que a entendem integrante da noção republicana (entre os direitos individuais - art. $60, \S 4^{\circ}$, IV); donde crermos que, se a razão não se encontra com GERALDO ATALIBA ("O Autor entende que o princípio republicano, muito embora não expresso diretamente... foi mantido na Constituição de 1988 como 'cláusula pétrea' [dependente apenas do resultado do plebiscito], eis que está ele consagrado nos demais princípios estabelecidos no $\S 4^{\circ}$ do art. $60 . . . "-$ República e constituição, atualiz. Rosolea Miranda Folgosi, 2. ed., São Paulo: Malheiros, 1998, p. 39, n.a. 1), certamente encontrarse-á com PINTO FERREIRA ("A essência da república está no voto direto, secreto, universal e periódico..." - Comentários à Constituição Brasileira, v. 3, São Paulo: Saraiva, 1992, p. 212). Para CÁRMEM LÚCIA ANTUNES ROCHA, entre a promulgação constitucional e o plebiscito de 1993, a república não foi cláusula pétrea, pela possibilidade de sua modificação pela via revisional, após o quê, recobrou sua condição de imodificável, como limite material implícito (República e federação..., op. cit., p. 70, 86 e 88-89). ROQUE ANTONIO CARRAZZA prefere ver, no dispositivo constitucional, a petrificação dos reflexos republicanos (Curso de direito constitucional tributário, 16. ed., São Paulo: Malheiros, 2001, p. 68-70).

18 República e constituição, São Paulo: RT, 1985, p. XI e XIV; na segunda edição, op. cit.: p. 15 e 18. 
Define-o a pena do mestre como "...o regime político em que os exercentes de funções políticas (executivas e legislativas) representam o povo e decidem em seu nome, fazendo-o com responsabilidade, eletivamente e mediante mandatos renováveis periodicamente". Não obstante pôr friso na idéia de igualdade, não é discrepante a visão de ROQUE ANTONIO CARRAZZA, para quem "República é o tipo de governo, fundado na igualdade formal das pessoas, em que os detentores do poder político exercem-no em caráter eletivo, representativo (de regra), transitório e com responsabilidade". ${ }^{19}$

Dessarte, pode-se inferir que caracterizam a República: a representatividade, decorrente da eletividade, a transitoriedade e a responsabilidade. Traços entre os quais cumpre conceder relevo ao primeiro deles, pois a República é, antes e acima de tudo, aquele regime de governo em que as autoridades são meros administradores da coisa pública - res publica - a título de mandatários do povo, que detém a sua propriedade.

Daí assistir integral razão a GERALDO ATALIBA quando coloca a idéia de mandato como "Pedra de toque do sistema... ponto de referência dos demais institutos informadores da República...”, localizando-o “...no centro de toda construção jurídica da República". ${ }^{20}$

Os poderes atribuídos aos mandatários do povo só descobrem sentido na idéia de função, na idéia de meios para a realização do interesse público. A ênfase em tais poderes, marco de uma época que já deixamos para trás, deve ceder espaço ao acento posto nos seus deveres em relação às finalidades consagradas na lei. Somente para cumpri-los e para atingi-las é que se lhes outorgam poderes. Daí a inclinação de muitos autores modernos, recorda MARCELO CAETANO, denominando-os poderes-deveres, nomenclatura que ganhou divulgação a partir de SANTI ROMANO, como lembra CELSO ANTÔNIO BANDEIRA DE MELLO. ${ }^{21}$

Nenhum, porém, meditando à luz da noção funcional, logrou projetar tão longe suas conseqüências, como o fez CELSO ANTÔNIO, chegando a propor "uma inversão do binômio: deveres-poderes mais do que poderes-deveres”. ${ }^{22}$ Não obstante a questionabilidade dessas expressões híbridas perante a

19 GERALDO ATALIBA, ibidem, p. IX; na edição atualizada, ibidem: p. 13. ROQUE ANTONIO CARRAZZA, Curso..., op. cit., p. 40.

20 Ibidem, p. 64-65; na edição atualizada, ibidem: p. 90-91.

21 CAETANO, Marcelo. Princípios fundamentais do direito administrativo. Rio de Janeiro: Forense, 1977, p. 141. MELLO, Celso Antônio Bandeira de. Elementos de direito administrativo. 2. ed., São Paulo: RT, 1990, p. 53; e Curso de direito administrativo, 12. ed., São Paulo: Malheiros, 2000, p. 69.

22 Controle Judicial dos Atos Administrativos, Revista de Direito Público, n. 65, São Paulo, RT, jan./mar. 1983, p. 31; Princípios Fundamentais de Direito Administrativo, In: CELSO ANTÔNIO BANDEIRA DE MELLO (coord.), Curso de direito administrativo, São Paulo: RT, 1986, p. 22; Legalidade, Motivo 
Lógica Jurídica, ${ }^{23}$ é forçoso reconhecer a irrecusável coerência da proposta desse eminente publicista, uma vez que os poderes não passam de simples instrumentos conferidos ao administrador público, de sorte a equipá-lo na incessante procura do atender às finalidades legais. Aí seus deveres inafastáveis.

Este é o momento e o local para aduzirmos ao tema "a teoria da Relação de Administração" que, a despeito de formulada no âmbito do Direito Administrativo, exprime com precisão a representatividade republicana, opondo o dono da coisa pública (o povo) ao seu administrador (governante, representante, mandatário). ${ }^{24}$ Essa teorização foi virtuosamente urdida e composta por aquele que os mestres apresentam como seu mestre. Não é prudente mais do que transcrever com respeito as asserções geniais que faz, ao opor as idéias de propriedade e de administração, esta típica do Direito Público, aquela característica do Direito Privado, o grande RUY CIRNE LIMA, jurista dos pampas e do Brasil, para o nosso justo orgulho:

"A palavra administração ... designa geralmente a atividade do que não é proprietário - do que não é senhor absoluto... Administração, segundo o nosso modo de ver, é a atividade... do que não tem a disposição da cousa ou do negócio administrado... Na administração, o dever e a finalidade são predominantes; no domínio, a vontade... O fim - e não a vontade - domina todas as formas de administração... Supõe, destarte, a atividade administrativa a preexistência de uma regra jurídica, reconhecendo-lhe uma finalidade própria... À relação jurídica que se estrutura ao influxo de uma finalidade cogente, chama-se relação de administração... (sic) (grifamos) ${ }^{25}$

Em lugar de nossa avaliação pessoal, de pouco significado, lançamos mão das palavras daquele publicista que, com tanto brilho, versou o tema da República, e cujo depoimento acerca da Relação de Administração, tal como vista por CIRNE LIMA, é dos mais expressivos:

"Na verdade, a idéia de representação e o instituto do mandato, como fulcros da concep̧̧ão republicano-democrática - do ponto de vista jurídico explicam-se pela relação de administração, que entre nós encontrou seu

e Motivação do Ato Administrativo, Revista de Direito Público n. 90, São Paulo: RT, abr./jun. 1989, p. 60; Elementos..., op. cit., p. 23 e 52-55; e Curso..., op. cit., p. 32 e 68-70.

23 São questionáveis, perante a Lógica Jurídica, essas expressões, poderes-deveres ou deveres-poderes, uma vez que, nas normas jurídicas, ocorre a tripartição do universo da conduta nos chamados modais deônticos, obrigatório, permitido e proibido, na lição de LOURIVAL VILANOVA (Lógica jurídica, São Paulo: Bushatsky, 1976, p. 124-126; As estruturas lógicas e o sistema do direito positivo, São Paulo: RT e EDUC, 1977, p. 37-38). Em verdade, cremos que, na versão tradicional (poderes-deveres), concede-se destaque ao primeiro membro do binômio, e estamos em presença do modal permitido; enquanto na versão mais recente (deveres-poderes), o friso posto nos deveres revela o modal obrigatório.

24 GERALDO ATALIBA, República..., op. cit., p. 64 e 68; na edição atualizada, op. cit., p. 90 e 94.

25 Princípios de direito administrativo, 6. ed., São Paulo: RT, 1987, p. 20, 22, 52, 22 e 51. 
expositor máximo em RUY CIRNE LIMA..." (grifamos) (GERALDO ATALIBA $)^{26}$

Apertemos agora o olhar para a idéia de representação, ainda navegando em águas republicanas, e no centro delas, mas já lhes reconhecendo aqui o influxo da correnteza democrática.

A aproximação entre as noções de República e de Democracia data dos antigos, como se pode ver em CÍCERO (NICOLLA MATTEUCCI e CÁRMEN LÚCIA ANTUNES ROCHA) ${ }^{27}$ Considere-se, por exemplo, do século XVIII, a referência de JAMES MADISON, nos célebres comentários à constituição norte-americana - "O Federalista”: “...la confusión de los conceptos de república y democracia...”. ${ }^{28}$ E considere-se também, dos nossos dias, a conclusão de CÁRMEN LÚCIA ANTUNES ROCHA, voltada para o nosso caso: "Os princípios republicano e democrático modelam-se e condicionam-se reciprocamente... Os dois princípios estão fundidos e condenados a serem tomados como uma expressão única e indissociável enquanto vigorar o atual sistema: República Democrática". 29

Antes de nos debruçarmos sobre a segunda dessas noções, registremos que, a exemplo do que ocorreu com a filosofia, como já tivemos oportunidade de consignar, também a democracia constitui uma invenção dos gregos. ${ }^{30}$ FERNANDO SAVATER recorre a um episódio da Guerra de Tróia, quando Aquiles, o grande guerreiro grego, afasta-se dos combates, por zangar-se com Agamenon, que chefiava o famoso cerco, como rei e cunhado da bela Helena, a quem os gregos buscavam recuperar dos troianos. Estabelecida a discussão entre os chefes aqueus, com a participação de Ulisses, para acolher a decisão da maioria; assinala SAVATER que, nessa passagem da "Ilíada", "...o que no fundo Homero está contando são os albores da democracia..." ${ }^{11}$ Nada mais do que uma experiência incipiente e muito restrita, a dos gregos, pois, entre eles, ficavam de fora das decisões as mulheres, os escravos e os estrangeiros residentes,

26 República..., op. cit., p. 64; na edição atualizada, op. cit., p. 90.

27 NICOLA MATTEUCCI, República, in: BOBBIO, Norberto; MATTEUCCI, Nicola; PASQUINO, Gianfranco. Dicionário de política, 3. ed., v. 2, trad. Carmen C. Varrialle et al., Brasília: UnB e Linha Gráfica, 1991, p. 1107 e 1108. CÁRMEN LÚCIA ANTUNES ROCHA, República..., op. cit., p. 22.

28 El Federalista - XIV, in: HAMILTON, Alexander; MADISON, James; JAY, John. El Federalista. México: Fondo de Cultura Económica, 2000, p. 53.

29 República..., op. cit., p. 69.

30 Quanto à precedência grega na filosofia, invocamos, para defendê-la, as reflexões insuspeitas de FRIEDRICH NIETZSCHE, de GUILLERMO FRAILE e de MARILENA CHAUÍ - A Noção de Sistema no Direito, Revista da Faculdade de Direito da UFPR, n. 33, Porto Alegre: Síntese, 2000, p. 55.

31 Politica..., op. cit., p. 71-73. 
anota o autor em outra obra; "Lo cual en nada disminuye la importancia radical, incomparable, del primer paso", 32 que exigiu nada menos que uma "...certa loucura..." - "Felizmente, os gregos eram meio loucos e de sua genial loucura ainda agora nos alimentamos". 33

Curioso que, seja qual for o posicionamento ou matiz ideológico, dentro do mais largo espectro imaginável, todos, sem exceção, tendem hoje a proclamar-se democráticos. E não raro, diante do seu estranho fascínio (IGNACIO DA SILVA TELLES), ${ }^{34}$ “...se entredevoram pela democracia”, como depõe MANOEL GONÇALVES FERREIRA FILHO. ${ }^{35}$ Tão elevado é o grau de polissemia do termo, como confirmam LOURIVAL VILANOVA e MISABEL DE ABREU MACHADO DERZI; ${ }^{36}$ a ponto de LUÍS ALBERTO WARAT dizê-lo contaminado por uma "anemia significativa" ${ }^{37}$ ou "anemia semântica" ${ }^{38}$

Mais do que nunca, pois, abre-se espaço para o "processo de elucidação" que pregava RUDOLF CARNAP, integrante do Círculo de Viena e ex-professor da Universidade de Chicago. ${ }^{39}$ Processo em que, numa primeira etapa, surpreendemos, na origem grega de democracia, o significado etimológico de governo ou poder do povo ${ }^{40}$ confirmado pela investigação filosófico-política do século XX, desde HANS KELSEN ${ }^{41}$ até RÉGIS DEBRAY e JUAN RAMÓN CAPELLA. ${ }^{42}$ Um passo adiante, NORBERTO BOBBIO aponta-a como a forma de governo em que “...o poder não está nas mãos de um só ou de poucos, mas de todos, ou melhor, da maior parte... da maioria....".33

32 Diccionario filosófico, México: Planeta, 1999, p. 80-81.

33 Política..., op. cit., p. 74-84.

34 A experiência da democracia liberal, São Paulo: RT, 1977, p. 75.

35 Curso de direito constitucional, 17. ed., São Paulo: Saraiva, 1989, p. 84.

36 LOURIVAL VILANOVA, Novo Poder Executivo para o Brasil, in: AURÉLIO WANDER BASTOS et al, Uma nova organização político-constitucional para o Brasil de hoje, Fortaleza, UFC, 1982, p. 115. MISABEL DERZI, Nota de Atualização $\mathrm{n}^{\circ} 2$ ao art. 96, in: ALIOMAR BALEEIRO, Direito Tributário Brasileiro, 11. ed., Rio de Janeiro: Forense, 1999, p. 610.

37 Apud STRECK, Lenio Luiz; MORAIS, José Luiz Bolzan de. Ciência política e teoria geral do estado. Porto Alegre: Livraria do Advogado, 2000, p. 97.

38 Apud SANTI, Eurico Marcos Diniz de. Decadência e prescrição no direito tributário. São Paulo: Max Limonad, 2000, p. 71.

39 Apud WARAT, Luis Alberto. O direito e sua linguagem. Porto Alegre: Fabris, 1984, p. 57.

40 CUNHA, Antônio Geraldo da. Dicionário..., op. cit., p. 246 e 224-225.

41 A democracia. Trad. Ivone Castilho Benedetti et al., São Paulo: Martins Fontes, 1993, p. 140; Escritos sobre la democracia y el socialismo, trad. Juan Ruiz Manero et al., Madrid, Debate, 1988, p. 208.

42 RÉGIS DEBRAY, La república ..., op. cit., p. 19. JUAN RAMÓN CAPELLA, Os Cidadãos..., op. cit., p. 68; que cogita de "...autogoverno das populações pelas populações mesmas...".

43 Liberalismo e democracia. Trad. Marco Aurélio Nogueira, 3. ed., São Paulo: Brasiliense, 1990, p. 7 e 31. 
No que diz respeito à evolução histórica desse conceito, fiquemos com este mesmo eminente teórico geral do direito e filósofo político italiano, que distingue a democracia dos antigos (direta) da democracia dos modernos (representativa) $;^{44}$ no que é seguido por vasta doutrina, da qual citamos, exemplificativamente, FRANCISCO RUBIO LLORENTE, o constitucionalista da Universidade Complutense de Madri. ${ }^{45}$ Pouco diversa é a visão de MANOEL GONÇALVES FERREIRA FILHO, que aponta três fases diversas: Democracia Antiga (direta), Democracia Moderna (representativa) e Democracia Contemporânea (participativa), fase esta última para a qual o constitucionalista do Largo São Francisco prefere a denominação de Poliarquia, no sentido de "o governo de muitos", acatando sugestão de ROBERT DAHL. ${ }^{46}$

Em face, contudo, dos limites estreitos do presente trabalho, contentemonos com a identificação do mínimo semântico da voz Democracia. E o fazemos, uma vez mais, em honrosa companhia: "...forma pela qual o poder (cuja suprema manifestação está em fazer leis) é exercido pelo povo ou por seus representantes eleitos” (MISABEL DERZI); “...democracia existirá... ali onde a vontade estatal... contenha mediata ou imediatamente a participação do povo" (LOURIVAL VILANOVA). ${ }^{47}$

Ora, é no procedimento legislativo, nos atos da produção legislativa que, indiscutivelmente, se surpreende a realização por excelência dessa dimensão participativa popular. Eis que, nessa porção mínima da noção conceptual de Democracia, identifica-se uma indefectível conexão com o Princípio da Legalidade; e evidente que, se não o bastante para o desabrochar democrático em sua plenitude, mais do que o suficiente para reconhecer-lhe uma manifestação efetivamente substancial.

Afinal, entre as decisões democráticas cuja tomada cabe originariamente ao povo, via representação política, ergue-se magnífica e soberana a decisão primordial da elaboração legislativa, nas palavras de SAVATER, “....antes privilegio inamovible de los dioses o capricho indiscutible de los tiranos"; consubstanciadora da autonomia política pela qual se recusam inapelavelmente todas as leis cuja promulgação não advenha dos representantes legitimamente

44 Ibidem, p. 31-36.

45 Estado e Democracia na Construção da Europa, trad. Fernando Aurelio Zilveti e Ana Marta C. de Barros Zilveti, in: Sérgio Resende de Barros e Fernando Aurelio Zilveti (coord.), Direito constitucional: estudos em homenagem a Manoel Gonçalves Ferreira Filho, São Paulo: Dialética, 1999, p. 127.

46 A democracia no limiar do século XXI, São Paulo: Saraiva, 2001, p. 1-36.

47 MISABEL DERZI, Nota de Atualização n 2 ao art. 96, Direito..., op. cit., p. 611; LOURIVAL VILANOVA, Novo Poder..., op. cit., p. 113-114. 
habilitados. ${ }^{48}$ Com efeito, como proclamou VICTOR HUGO, o literato de Os Miseráveis, "Quem vota reina!" 49

E complete-se a referência a essa noção mínima de Democracia invocando, de conformidade com as lições kelsenianas, o princípio da maioria na determinação da ordem social. Trata-se, no dizer de BOBBIO, de "...regra fundamental da democracia...". ${ }^{50}$ Entretanto, regra majoritária que convive com $o$ direito da minoria: "A maioria pressupõe... a existência de uma minoria... Se a minoria não for eliminada do procedimento no qual é criada a ordem social, sempre existe uma possibilidade de que a minoria influencie a vontade da maioria" (HANS KELSEN).$^{51}$ Direito da minoria este que deve seguir inatacável e intocável, sob pena de inconsistência democrática, porque a regra majoritária sozinha não faz democracia: "Las decisiones democráticas son mayoritarias, pero no toda decisión mayoritaria es democrática. Ninguna mayoría tiene derecho democrático a votar a favor de la sumisión sin derechos de las minorías..." (FERNANDO SAVATER); ${ }^{52}$ "La democracia no es el reino de la mayoría. Hay democracia cuando la minoría conserva sus derechos de expresión y de organización" (RÉGIS DEBRAY). ${ }^{53}$

Sem enveredar pelo aprofundamento do conceito democrático, tarefa que extravasaria as nossas, no particular, pouco ambiciosas fronteiras, limitemonos ao registro da convicção que partilhamos com MISABEL DERZI, no sentido de que a democracia, que o legislador da Carta de 1988 nela consagrou, vai além desse miolo significativo mínimo, ultrapassando a legalidade formal, e firmando compromisso de ordem material com a liberdade e a igualdade. ${ }^{54}$ Cogitase aqui da realização mais radical desses valores - fundamentos irrecusáveis da democracia (NORBERTO BOBBIO) $)^{55}$ - de forma a transcender a mera liberdade assegurada pela igual participação na gestão pública, mediante, principalmente, o exercício da liberdade da igual participação nas decisões legislativas; para galgar patamar substancialmente superior, em que a todos seja assegurada a possibilidade de realização de suas capacidades, através de uma efetiva igual-

48 Diccionario.., op. cit., p. 80 e 89.

49 No original francês: "Qui vote règne" - Apud JUAN RAMÓN CAPELLA, Os cidadãos..., op. cit., p. 135 , nota $\mathrm{n}^{\circ} 184$.

50 O futuro..., op. cit., p. 19.

51 Teoria geral do direito e do estado. Trad. Luís Carlos Borges, São Paulo/Brasília: Martins Fontes e UnB, 1990, p. 280-281.

52 Diccionario..., op. cit., p. 95; e Política ..., op. cit., p. 183.

53 La república..., op. cit., p. 23.

54 Nota de Atualização ${ }^{\circ} 2$ ao art. 96, Direito..., op. cit., p. 611.

55 Igualdade e liberdade, op. cit., p. 8. 
dade de oportunidades, de modo que a ninguém seja recusado o exercício de sua cidadania por força das amarras econômicas que o mantenham refém de suas necessidades vitais básicas. ${ }^{56}$

Demo-nos por satisfeitos, aqui, com a identificação do nosso próximo passo, a estação primeira onde desagua incontida a representatividade republicano-democrática - a legalidade.

Antes, contudo, ponhamos friso em uma idéia que já sobressai nesse mínimo essencial da democracia, valendo-nos da voz privilegiada de OCTAVIO PAZ, o soberbo escritor mexicano, Prêmio Nobel de Literatura de 1990, para quem "...la democracia... es un método de convivencia civilizada... pide que cada uno sea capaz de convivir com su vecino, que la minoría acepte la voluntad de la mayoría, que la mayoría respete a la minoría y que todos preserven y defiendan los derechos de los individuos" (grifamos). ${ }^{57}$ De fato, democrático é, sem dúvida, o convívio pacífico das discordâncias e a convivência serena das divergências. Não por outra razão, MARILENA CHAUÍ apresenta a democracia como “...a única sociedade e o único regime político que considera o conflito legítimo"; ${ }^{58}$ e diverso não calharia ser, porque o conflito é intimamente próprio do humano.

Ao fim do segmento, a sábia eloqüência do filósofo espanhol do vitalismo, que encontra um índice seguro de vida civilizada já nessa noção menor de democracia, tão admirável que lhe parece beirar a incompreensão. Com a palavra ORTEGA Y GASSET:

"Civilização é, antes de tudo, vontade de convivência. É-se incivil e bárbaro na medida em que não se conte com os demais. A barbárie é tendência à dissociação...

A forma que na política representou a mais alta vontade de convivência é a democracia liberal... o Poder público, não obstante ser onipotente, limita-se a sí mesmo e procura, ainda a sua custa, deixar espaço no Estado que êle impera para que possam viver os que nem pensam nem sentem como êle, quer dizer, como os mais fortes, como a maioria... é a suprema generosidade: é o direito que a maioria outorga à minoria e é, portanto, o mais nobre grito que soou no planêta. Proclama a decisão de conviver com o inimigo; mais ainda, com o inimigo débil. Era inverossímil que a espécie humana houvesse chegado a uma coisa tão bonita, tão paradoxal, tão elegante, tão acrobática...

56 FERNANDO SAVATER, Diccionario..., op. cit., p. 86-91; RÉGIS DEBRAY, La República ..., op. cit., p. 78.

57 Apud FERNANDO SAVATER, Diccionario..., op. cit., p. 94.

58 Convite à filosofia, 4. ed., São Paulo, Ática, 1995, p. 433. 
Conviver com o inimigo! Governar com a oposição! Não começa a ser já incompreensível semelhante ternura?"' $(\text { sic })^{59}$

\section{LEGALIDADE}

\subsection{Legalidade genérica}

A melhor reflexão, talvez, relativa à controvérsia que se instaurou na doutrina sobre a natureza do Princípio da Legalidade, coube a ANDRÉ GONÇALVES PEREIRA, ${ }^{60}$ eminente publicista lusitano, da qual encontramos boa síntese em WEIDA ZANCANER, ${ }^{61}$ subsídios dos quais já nos valemos no passado. $^{62}$

Discorre o jurista luso a respeito de uma concepção restritiva do Princípio da Legalidade (não infringir a lei), já ultrapassada; bem como a respeito de uma concepção ampliativa (agir nos termos da lei), a que dá sua adesão, fazendo-a remontar a GUIDO ZANOBINI.

Socorre-se GONÇALVES PEREIRA, como o fazemos agora nós, da bem construída teoria de CHARLES EISENMANN, ex-professor da Faculdade de Direito e de Ciências Econômicas de Paris, para identificar a concepção restritiva do princípio com uma relação de não-contrariedade ou de compatibilidade (agir de modo não contrário ou compatível com a lei, que só fixa limites - o que não é proibido é permitido), numa noção mínima de legalidade; e para identificar a concepção ampliativa com uma relação de conformidade (agir conforme a lei, que fixa limites e permissões expressas - o que não é permitido é proibido), numa noção máxima de legalidade. ${ }^{63}$

A visão restritiva do Princípio da Legalidade (relação de compatibilidade) consubstancia, na doutrina alemã, o que se denomina Princípio da Preeminência da Lei, enquanto a visão ampliativa (relação de conformidade) identifica-se com o Princípio da Reserva da Lei, como noticia ALBERTO XAVIER. ${ }^{64}$

59 A rebelião das massas. Trad. Herrera Filho, Rio de Janeiro: Ibero-Americano, 1959, p. 120-121.

60 Erro e ilegalidade no acto administrativo, Lisboa: Ática, 1962, p. 20-29 e 38-40.

61 Da convalidação e da invalidação dos atos administrativos, São Paulo: RT, 1990, p. 17-18.

62 JOSÉ ROBERTO VIEIRA, Princípios constitucionais e estado de direito, Revista de Direito Tributário $\mathrm{n}^{\circ}$ 54, São Paulo, RT, out./dez. 1990, p. 96-97; O princípio da legalidade da administração, Revista de Direito Público n ${ }^{\circ}$ 97, São Paulo, RT, jan./mar. 1991, p. 143-149.

63 O direito administrativo e o princípio da legalidade, Revista de Direito Administrativo, $\mathrm{n}^{\circ}$ 56, Rio de Janeiro, FGV, abr./jun. 1959, p. 54-57.

64 Os princípios da legalidade e da tipicidade da tributação, São Paulo: RT, 1978, p. 13-16. 
Por seu turno, RENATO ALESSI, o admirável publicista italiano, refere-se ao ângulo restritivo (relação de compatibilidade) como o sentido negativo do Princípio da Legalidade, e como sentido positivo do princípio ao ângulo ampliativo (relação de conformidade). Aliás, calha oportuno transcrevê-lo, não só para mostrar-lhe a terminologia, mas especialmente para frisar sua opção, que ilustra a de toda a boa doutrina:

“...tal subordinação, que concretiza o princípio da necessária legalidade... é entendida antes de tudo em sentido negativo: vale dizer, no sentido de que a atividade... encontra um limite formal insuperável na lei, a qual pode estabelecer proibições a determinadas atividades... mas, entendida, também e sobretudo, em sentido positivo... no sentido de que, como melhor se verá a seu tempo, a administração, particularmente no que concerne à atividade de caráter jurídico, pode fazer apenas o que a lei consente" ${ }^{95}$

A menção ao fato de que a percepção do princípio deve ser em sentido negativo, mas "também e sobretudo" em sentido positivo, traz à tona o problema das conexões entre uma e outra relação. Na verdade, a interpretação ampliativa do Princípio da Legalidade aceita e abrange a interpretação restritiva, adicionando, porém, novo e relevante conteúdo ao princípio. Tal implicação não escapou a EISENMANN, que assim dela cuidou: "O caráter de conformidade inclui em si mesmo o de compatibilidade: o objeto conforme é, por essência, compatível... Mas a recíproca não é verdadeira: o caráter de compatibilidade não inclui de forma alguma o de conformidade, é distinto, e suscetível de uma existência autônoma e isolada". ${ }^{66}$

No direito pátrio não hesitamos em proclamar o Princípio da Legalidade como uma relação de conformidade com a lei em sentido formal, ato oriundo do órgão que detém a competência constitucional para legislar e revestido da forma estabelecida para as leis, e não só em sentido material, como regra de comportamento genérica e coativa.

Prescreve o Estatuto Constitucional brasileiro, em seu art. 5ํ, II, que "ninguém será obrigado a fazer ou deixar de fazer alguma coisa senão em virtude de lei". E mais, no art. 84, IV, que "compete privativamente ao Presidente da República: sancionar, promulgar e fazer publicar as leis, bem como expedir decretos e regulamentos para sua fiel execução"; ou seja, até aos mais eminentes

65 Sistema istituzionale del diritto amministrativo italiano, 3. ed., Milano, Giuffrè, 1960, p. 9. No original italiano: "...tale subordinazione che concreta il principio della necessaria legalità... va intesa anzitutto in senso negativo: vale a dire, nel senso che l'attività... trova un limite formalmente insuperabile nella legge, la quale può porre divieti a determinate attività... va intesa inaltro e soprattuto, in senso positivo.... nel senso che, come meglio si vedrà a suo tempo, l'amministrazione, particolarmente per quanto concerne l'attività di carattere giuridico, può fare soltanto ciò che la legge consente". 
atos administrativos, decretos e regulamentos presidenciais, não é dado ir além da humilde execução da lei.

Definitivamente afastados, pois, os regulamentos autônomos, que não desfrutam do mínimo espaço jurídico em face do nosso direito positivo. Aliás, DIÓGENES GASPARINI foi talvez quem melhor advogou, entre nós, a causa dos regulamentos independentes. ${ }^{67}$ Muito significativo, por conseguinte, que, sete anos depois de tê-lo feito, haja empreendido recuo, admitindo expressamente a impropriedade da afirmação de tais regulamentos na ordem jurídica nacional..$^{68}$

São eloqüentes os testemunhos de apoio de que dispomos, no tema: o de ROQUE ANTONIO CARRAZZA, seguido por HUMBERTO BERGMANN ÁVILA, asseverando que esses regulamentos “...não existem no Brasil”; 69 o de CLÈMERSON MERLIN CLÈVE, recusando-lhes lugar em nosso ordenamento; ${ }^{70}$ o de JOSÉ EDUARDO SOARES DE MELO, entendendo-os inconcebíveis; ${ }^{71}$ o de CELSO ANTÔNIO BANDEIRA DE MELLO, dizendoos "...visceralmente incompatíveis com o direito brasileiro;" 72 e o de GERALDO ATALIBA, num primeiro momento, condenando-os por incabíveis, noutro, posterior, considerando o comportamento de quem lhes dedique estudo entre nós, para tachá-lo de cientificamente "ridículo". ${ }^{73}$

Valemo-nos, linhas atrás, da expressão Princípio da Reserva da Lei, veiculando posicionamento doutrinário germânico, que assim se refere à interpretação ampliativa da legalidade (relação de conformidade). Entretanto, é apropriado o momento para acusar o vezo de boa parte da doutrina brasileira,

67 Poder regulamentar, 2. ed., São Paulo: RT, 1982, especialmente p. 123-156.

68 Direito administrativo, São Paulo: Saraiva, 1989, p. 95; posicionamento mantido em edição posterior dessa obra: 3. ed., São Paulo: Saraiva, 1993, p. 112-114.

69 CARRAZZA, Roque Antonio. O regulamento no direito tributário brasileiro. São Paulo: RT, 1981, p. 12, n. 19; Curso..., op. cit., p. 313. ÁVILA, Humberto Bergmann. Medida Provisória na Constituição de 1988. Porto Alegre: Fabris, 1997, p. 63.

70 Medidas provisórias, 2. ed., São Paulo: Max Limonad, 1999, p. 34; Atividade legislativa do poder executivo, 2. ed., São Paulo: RT, 2000, p. 293-294

71 Curso de direito tributário, 2. ed., São Paulo: Dialética, 2001, p. 133.

72 Elementos..., op. cit., p. 59; Curso..., op. cit., p. 74.

73 Apontamentos de ciência das finanças, direito financeiro e tributário, São Paulo: RT, 1969, p. 119: "Não tem cabimento, no nosso regime, o regulamento autônomo. Os que expõem as explicações para sua existência fazem, cientificamente, demonstração de erudição em matéria de direito alienígena e ignorância do nosso direito constitucional; didaticamente, prestam um desserviço, por induzirem em erro aos mais inadvertidos; politicamente contribuem para reforçar o caráter ditatorial dos nossos governos, amesquinhando nossas conquistas jurídicas" (sic). República..., op. cit., p. 121; na edição atualizada, op. cit:: p. 148. 
que faz uso da mesma expressão como sinônimo de Princípio da Legalidade. $\mathrm{O}$ procedimento seria legítimo se nossa Constituição, como a da França, por exemplo, guardasse para a lei um taxativo rol de matérias, estabelecendo que “...A lei estabelece as regras concernentes a:... A lei estabelece igualmente as regras concernentes a:..." - reserva de lei (art. 34); e preservasse outra lista exaustiva de assuntos ou, como no caso francês, um campo residual para o regulamento, estabelecendo que "As outras matérias, fora do domínio da lei, terão caráter regulamentar" - reserva regulamentar (art. 37) $7^{74}$ no que fazemos coro com LUCIANO FERREIRA LEITE. ${ }^{75}$ Vimos, porém, pelos comandos constitucionais a que há pouco recorremos, que outra é a nossa realidade normativa, onde é plena a competência da lei, dependendo os decretos e regulamentos unicamente da preexistência de lei cuja execução fiel motive sua expedição. Identificamos aí, tal como no caso dos regulamentos autônomos, a transposição acrítica de doutrina forasteira, que não se harmoniza em absoluto com nosso ordenamento. ${ }^{76}$

É que o alcance da lei e dos atos normativos em geral varia de um para outro ordenamento na exata proporção do desenho que lhe riscou o respectivo legislador. Registrou-o MANUEL AFONSO VAZ: “...o princípio da legalidade e os problemas com ele conexos dependem da estrutura de cada ordenamento constitucional....".7

Tão robusto é o papel do Princípio da Legalidade no Brasil, que PONTES DE MIRANDA viu-se impelido a cunhar-lhe novo rótulo, dada à sua especificidade e a despeito de riqueza da língua-mãe. Batizou-o de "legalitariedade". ${ }^{78}$

74 Constitución de la República Francesa, in: FRANCISCO RUBIO LLORENTE e MARIANO DARANAS PELÁEZ, Constituciones de los Estados de la Unión Europea, Barcelona: Ariel, 1997, p. 238-239. No original francês: "Article 34. ...La loi fixe les règles concernant:... La loi fixe également les règles concernant:..."; "Article 37. Les matières autres que celles qui sont du domaine de la loi ont un caractère réglementaire" (La Constitution française - A Constituição da França, trad. Embaixada da França, rev. Dulcydides de Toledo Piza, Rio de Janeiro, Embaixada da França, 1983, p. 24-26).

75 Discricionariedade administrativa e controle judicial, São Paulo: RT, 1981, p. 18-19.

76 Conquanto de acordo com essa reflexão, CESAR A. GUIMARÃES PEREIRA, em recente e valiosa contribuição científica, mantém a terminologia tradicional, estabelecendo porém a convenção de que o faz para aproveitar “...lições centenárias sobre os limites impostos à Administração pelo princípio da legalidade construído como reserva absoluta de lei formal" - Elisão tributária e função administrativa, São Paulo: Dialética, 2001, p. 148.

77 Lei e reserva da lei: a causa da lei na constituição portuguesa de 1976, Porto, Universidade Católica Portuguesa, 1992, p. 398.

78 Comentários à constituição de 1967 com a Emenda $n^{\circ} 1$ de 1969, t. V, 3. ed., Rio de Janeiro: Forense, 1987, p. 1 . 


\subsection{Legalidade tributária}

Legalitariedade que se projeta no capítulo tributário, configurando o Princípio da Estrita Legalidade da Tributação: “...é vedado à união, aos Estados, ao Distrito Federal e aos Municípios: ...exigir ou aumentar tributo sem lei que o estabeleça" (art. 150, I). Trata-se, na concepção de ALBERTO XAVIER, da "...mais importante de todas as limitações constitucionais ao poder de tributar...", reclamando lex scripta (que afasta o direito consuetudinário) e lex stricta (que arreda os atos de degrau inferior ao da lei, como os regulamentos). ${ }^{79}$ Trata-se, na visão de DIVA PRESTES MARCONDES MALERBI, do princípio “...que melhor edificou o arcabouço do sistema tributário brasileiro". ${ }^{80}$

Não se satisfez o legislador constitucional com a disposição genérica do art. $5^{\circ}$, II, indo além no detalhismo característico dos temas constitucionais tributários e formulando, na especificidade do art. 150, I, a exigência de lei para a instituição ou majoração de exações tributárias. Ora, que significa instituir tributo? Antes de tudo o mais, lembremos, com PAULO DE BARROS CARVALHO, que a aptidão constitucionalmente deferida para fazê-lo, vale dizer, a competência tributária, é uma competência legislativa. É legislando que se institui um tributo.$^{81} \mathrm{E}$ sigamos adiante com ROQUE ANTONIO CARRAZZA para completar: é editar, com suas minúcias todas, a norma jurídica tributária de incidência. ${ }^{82}$

O estudo da norma jurídica tributária, e especificamente da norma tributária de incidência, tem, entre nós, débitos vultosos irrecusáveis com juristas como ALFREDO AUGUSTO BECKER e GERALDO ATALIBA. ${ }^{83}$ Mas foi em PAULO DE BARROS CARVALHO que a estrutura da norma tributária encontrou sua mais precisa e sofisticada elaboração. Sua proposta teórica foi mais extensamente formulada na Teoria da Norma Tributária, de 1974, por diversas vezes retomada nas sucessivas reedições do seu Curso de Direito Tributário (capítulos IX a XI), encontrando sua última versão na obra recente Fundamentos Jurídicos da Incidência Tributária, de $1996 .{ }^{84}$

Assumimos, como PAULO DE BARROS, a visão kelseniana quanto à enunciação do Direito a partir da norma complexa, composta pela norma primária (a conduta desejada) e pela norma secundária (a sanção), nos termos da Teoria Geral das Normas, último posicionamento desse teórico do Direito que marcou indelevelmente

79 Os princípios..., op. cit., p. 4, 19-20 e 37-38.

80 Elisão tributária, São Paulo: RT, 1984, p. 77.

81 Curso de direito tributário, 13. ed., São Paulo: Saraiva, 2000, p. 212.

82 Curso..., op. cit., p. 215.

83 BECKER, Alfredo Augusto. Teoria geral do direito tributário. 2. ed. São Paulo: Saraiva, 1972; ATALIBA, Geraldo. Hipótese de incidência tributária. 5. ed. São Paulo: Malheiros, 1993.

84 Teoria da norma tributária, 3. ed., São Paulo: Max Limonad, 1998; Curso..., op. cit., p. 239-349; Fundamentos jurídicos da incidência tributária, São Paulo, 1996, Tese (Titular de Direito Tributário) - Universidade de São Paulo; esta última editada como Direito tributário: fundamentos jurídicos da incidência, 2. ed., São Paulo: Saraiva, 1999. 
este século. ${ }^{85}$ Ambas as normas portadoras da mesma estrutura sintática de um juízo hipotético, cujos segmentos desempenham diversas funções semânticas: a hipótese como descritora de um fato e a conseqüência como prescritora de uma relação jurídica. Fixando o olhar especificamente na norma jurídica de incidência tributária, ou, na terminologia de PAULO DE BARROS, na regra-matriz de incidência tributária, teremos, na hipótese de incidência tributária, um comportamento de pessoas (critério material), subordinado a uma condição de lugar (critério espacial) e a uma condição de tempo (critério temporal); e na conseqüência tributária, os sujeitos ativo e passivo (critério pessoal), a base de cálculo e a alíquota (critério quantitativo).

Visceralmente ligado aos Princípios da República e da Democracia, pela ponte da representatividade popular, também a Legalidade, inclusive a Tributária, como irrecusável direito e garantia individual do cidadão-contribuinte que constitui, nos termos expressos do art. 150, caput, encontra-se seguramente protegida entre as cláusulas de pedra da Lei Maior (art. 60, $4^{\circ}$, IV).

Apenas pelo caminho da lei é que o Direito brota espontâneo da sociedade, como quer ORTEGA Y GASSET. ${ }^{86}$ Exclusivamente por essa via é que se realiza à quase perfeição a proclamada soberania popular (art. $1^{\circ}$, parágrafo único). Somente por essa estrada é que o Direito ganha a dimensão da reflexividade e o homo juridicus salta das planícies da imposição para as altitudes da auto-imposição. Bem acentua o mestre GERALDO ATALIBA: "O apanágio do cidadão, no regime republicano, está exatamente na circunstância de só obedecer-se a si mesmo, pelos preceitos que seus representantes, em seu nome, hajam consagrado formalmente em lei". ${ }^{87}$ Afinal, "Si tu haces la ley, es normal que la cumplas. En caso contrario, no te respetas a ti misma(o)" (adaptamos) (RÉGIS DEBRAY).$^{88}$ Em matéria de tributos, o Princípio da Legalidade possibilita e realiza a idéia de autotributação.

\section{SONHO OU PESADELO}

Se vigiamos o cumprimento dos comandos que realizam a representatividade republicano-democrática. Mais: se velamos pelo respeito às regras que implementam a efetiva participação popular nas decisões legislativas. Mais ainda: se denunciamos o menoscabo pelas normas que prestigiam os valores fundamentais da liberdade e da

85 Teoria geral das normas, trad. José Florentino Duarte, Porto Alegre, Fabris, 1986, p. 181. Tal revisão kelseniana do seu próprio pensamento não encontra acolhida inteiramente pacífica: MARCOS BERNARDES DE MELLO, apontando contradições internas da obra no tema, e lembrando sua publicação póstuma, organizada pelo Instituto Hans Kelsen, de Viena, põe em dúvida o grau de convicção do autor, recomendando reservas na sua aceitação - Teoria do fato jurídico (Plano da Existência), 11. ed., São Paulo: Saraiva, 2001, p. 29-31, n. 35-A; argumento este último retomado por MARÇAL JUSTEN FILHO - Apud OCTAVIO CAMPOS FISCHER, A contribuição ao PIS, São Paulo: Dialética, 1999 , p. 27, n. 78.

86 A Rebelião..., op. cit., p. 23: “...o direito... é, se me permitem a expressão barroca, secreção espontânea da sociedade e não pode ser outra coisa".

87 República..., op. cit., p. 99; na edição atualizada, op. cit.: p. 125.

88 La república..., op. cit., p. 46. 
igualdade, inclusive e especialmente quando além do simplesmente formal. Por exemplo, em matéria tributária, se esclarecemos e apontamos os mandamentos que menosprezam o estreito compromisso do ordenamento com o Princípio da Capacidade Contributiva, desdenhando, por decorrência, o magno Princípio da Igualdade Tributária; como os da legislação do ICMS ou do IPI que agridem a Seletividade, ou os da legislação do Imposto de Renda ou do IPTU que insultam a Progressividade.

Se nossas respostas a esses e tantos outros semelhantes "ses" são indecisas, vacilantes, titubeantes, hesitantes; então não só não nos encontramos imbuídos de autêntico espírito republicano-democrático, como, pelo contrário, acabamo-nos voltando para a direção oposta, e elegendo como caminho e destino o domínio da Lei da Selva, a barbárie e a animalidade pré-histórica. Aí o pesadelo!

Se, em contrapartida, nossas respostas a esses e outros "ses" similares são firmes, decididas, determinadas, resolutas; então, ademais de revelarmos consciência republicana e democrática, mantemos o bom rumo, escolhendo como itinerário e porto de chegada o âmbito da Legalidade, a civilização e a humanidade de um porvir iluminado. Aí o sonho!

Hoje, quando findamos essas reflexões, vivemos a Páscoa de 2002. E Páscoa, do hebreu Pessah, tanto na tradição judaica do Antigo Testamento, festejando a passagem da escravidão no Egito para a liberdade da busca da terra prometida, quanto na tradição cristã do Novo Testamento, festejando a passagem da escravidão da morte para a liberdade da ressurreição, tem sempre o sentido de uma auspiciosa celebração libertadora. ${ }^{89}$ Que essa Páscoa, igualmente venturosa, nos inspire no sentido da passagem jurídico-política para uma visão mais consentânea com as exigências republicanas e democráticas de nossa Lei Mãe. Que ela nos estimule no sentido da passagem da tendência pela Lei da Selva para a inclinação pela Legalidade, inclusive Tributária. Que ela nos incite no sentido da passagem do pendor pelo pesadelo para a propensão pelo sonho.

E é cuidando do sonhar que concluímos; sonhar, para cuja exaltação tomamos emprestada a expressão literariamente cintilante de FRIEDRICH NIETZSCHE, que nos convoca com exuberância para a missão de sonhadores e andarilhos das alturas:

"Oh, esses homens de outrora sabiam sonhar, e nem precisavam antes adormecer! - e também nós, homens de hoje, ainda sabemos fazê-lo muito bem... o espírito e a força do sonho vêm sobre nós, e de olhos abertos e indiferentes ao perigo escalamos os mais perigosos caminhos, rumo aos telhados e torres da fantasia, sem qualquer vertigem, como que nascidos para escalar nós, sonâmbulos diurnos! Nós, artistas!... Nós, maníacos da Lua e de Deus! Nós, incansáveis e silenciosos andarilhos, em alturas que não vemos como alturas, mas como planícies, nossas certezas!"90

89 SCHLESINGER, Hugo; PORTO, Humberto. As religiões ontem e hoje. São Paulo: Paulinas, 1982, p. 206-207.

90 A gaia ciência. Trad. Paulo César de Souza, São Paulo: Companhia das Letras, 2001, p. 97. 